\title{
A new species of the genus Taikona Arita et O. Gorbunov, 2001 from the Malay Peninsula (Lepidoptera: Sesiidae)
}

\author{
Новый вид рода Taikona Arita et O. Gorbunov, 2001 с Малайского \\ полуострова (Lepidoptera: Sesiidae)
}

\author{
O.G. Gorbunov \\ О.Г. Горбунов
}

\begin{abstract}
A.N. Severtsov Institute of Ecology and Evolution, Russian Academy of Sciences, Leninsky prospekt 33, Moscow 119071, Russia. E-mail: gorbunov.oleg@mail.ru

Институт проблем экологии и эволюции им. А.Н. Северцова РАН, Ленинский проспект, 33, Москва 119071, Россия.
\end{abstract}

KEY WORDS: Lepidoptera, Sesiidae, Paranthrenini, Oriental Region, Taikona polevoyi, Taikona actinidiae, new species, new combination, systematics, Malaysia.

КЛЮЧЕВЫЕ СЛОВА: Lepidoptera, Sesiidae, Paranthrenini, Индо-Малайский регион, Taikona polevoyi, Taikona actinidiae, новый вид, новая комбинация, систематика, Малайзия.

ABSTRACT. A new clearwing moth species is described and illustrated from continental Malaysia: Taikona polevoyi sp.n. Paranthrene actinidiae Yang et Wang 1989 is transferred to the genus Taikona Arita et O. Gorbunov, 2001.

РЕЗЮМЕ. Дано иллюстрированное описание нового вида бабочки-стеклянницы из континентальной Малайзии - Taikona polevoyi sp.n. Paranthrene actinidiae Yang et Wang 1989 перенесён в состав рода Taikona Arita et O. Gorbunov, 2001.

\section{Introduction}

The genus Taikona Arita et O. Gorbunov, 2001 was established for a single Taiwanese species, T. matsumurai Arita et O. Gorbunov, 2001 [Arita, Gorbunov, 2001]. A decade later, Arita recordered this species from the Nanling National Nature Reserve, S China, Guangdong [Arita, 2011]. However, based by the image presented in that paper (pl. 3, fig. 28), this specimen belongs to another, still undescribed species of the genus Taikona. This becomes clear from a different pattern of coloration of the thorax and abdomen (cp. fig. 18 in Arita, Gorbunov [2001] and fig. 28 in Arita [2011]). Having studied the original description and available illustrations of Paranthrene actinidiae Yang et Wang 1989 from the Chinese province of Fujian, I come to the conclusion that this taxon is to be attributed to the genus Taikona and herewith I formally transfer it to this genus, Taikona actinidiae (Yang et Wang 1989), comb.n. Thus, at present I include the following three species into the genus: T. matsumurai Arita et O. Gorbunov, 2001 (type locality: Taiwan: Kaohsin Hsien, Tangchin), T. actinidiae (Yang et Wang 1989) (type locality: China: Fujian, Jianning), and T. polevoyi sp.n. (type locality: Malaysia: Pahang, Kauntan).

Kallies et al. [2014: 187], in their recent paper on Paranthrenini, wrote that "The genus Taikona is closely related to Nokona. It differs chiefly by its transparent forewings (usually but not always opaque in Nokona). Further study is required to establish whether Taikona is a separate genus or should be considered a synonym of Nokona". Of course, the genus Taikona is phylogenetically very close to the genus Nokona Matsumura, 1931 (type species: Paranthrene yezonica Matsumura, 1931, = Sciapteron feralis Leech, 1889) [Yata et al., 2017], but the forewings of all species of Nokona are not as transparent as in Taikona. It should be recalled that Nokona in the modern sense is a completely heterogeneous genus even within the eastern part of the Palaearctic [Gorbunov, 2016]. Increasing the species composition of the genus makes it possible to outline its following apomorphies: the almost completely transparent forewings, the extremely short veins $\mathrm{R}_{4}$ and $\mathrm{R}_{5}$, and the highly oblique cross-vein of both fore- and hindwing.

The type-series was collected by Mr. E. Polevoy (Moscow, Russia) using synthetic sex attractants produced by PHEROBANK ${ }^{\circledR}$, Wijk bij Duurstede, the Netherlands.

Figures of the types were taken with a Sony $\alpha 450$ DSLR camera with a Minolta 50 Macro lens. The habitat of the new species was photographed with a Sony $\alpha 350$ DSLR camera with a Sony lens. The genitalic images

How to cite this article: Gorbunov O.G. 2018. A new species of the genus Taikona Arita et O. Gorbunov, 2001 from the Malay Peninsula (Lepidoptera, Sesiidae) // Russian Entomol. J. Vol.27. No.3. P.293-296. doi: 10.15298/ rusentj.27.3.10 
were obtained using a Keyence BZ-9000 Biorevo Fluorescence Microscope. Final processing of all illustrations was performed with Adobe ${ }^{\circledR}$ Photoshop ${ }^{\circledR}$ CS5 .

The type-series is kept in the collection of A.N. Severtsov Institute of Ecology and Evolution of the Russian Academy of Sciences, Moscow, Russia(COGM). All labels of the holotype are shown in detail. Each label is separated by quotation marks, while lines on a label are shown separated by a slash ("“). All pictures of the holotype are labeled with a number which consists of the name of the family, two consecutive digits and a year (e.g., SESIIDAE pictures №№ 0061-0062-2013). These numbers correspond to those of the illustrated specimens

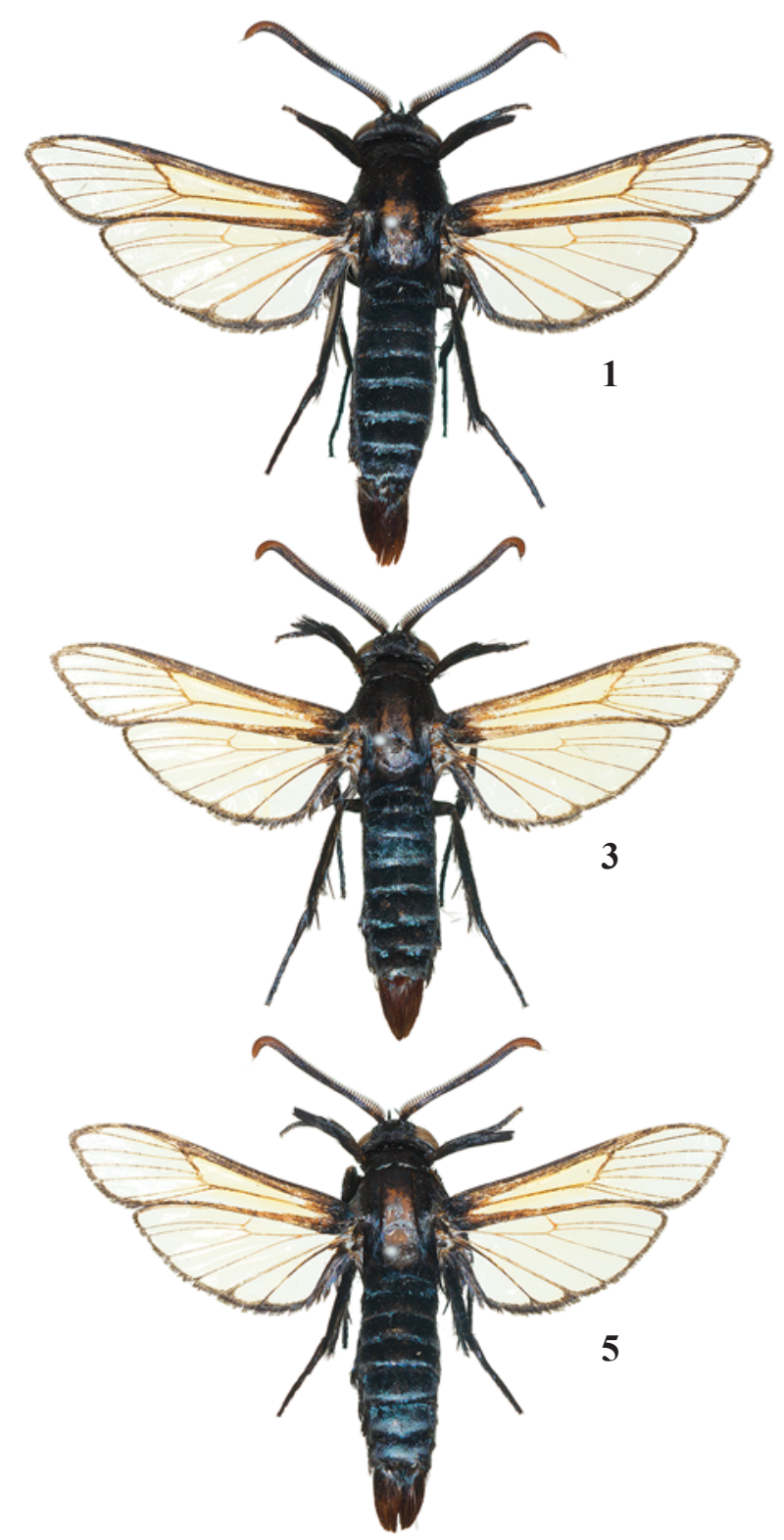

in the archives of the author. The genitalic preparation is appropriately numbered, placed in a microtube and pinned under the specimen. This number is also printed on a label (e.g., Preparation № OG-005-2018), pinned under the specimen and listed in the archives of the author.

\section{Description}

Taikona polevoyi O. Gorbunov, sp.n. Figs 1-12.

MATERIAL. Holotype $\sigma^{7}$ (Figs 1-2) with labels: "Malaysia, Pahang Prov., / Kauntan, Swiss Garden / Resort, $03^{\circ} 55^{\prime} \mathrm{N}, 103^{\circ} 22^{\prime} \mathrm{E}$, / 07.III.2011, / E. Polevoy leg.", "SESIIDAE / Pictures №№ / 0061-

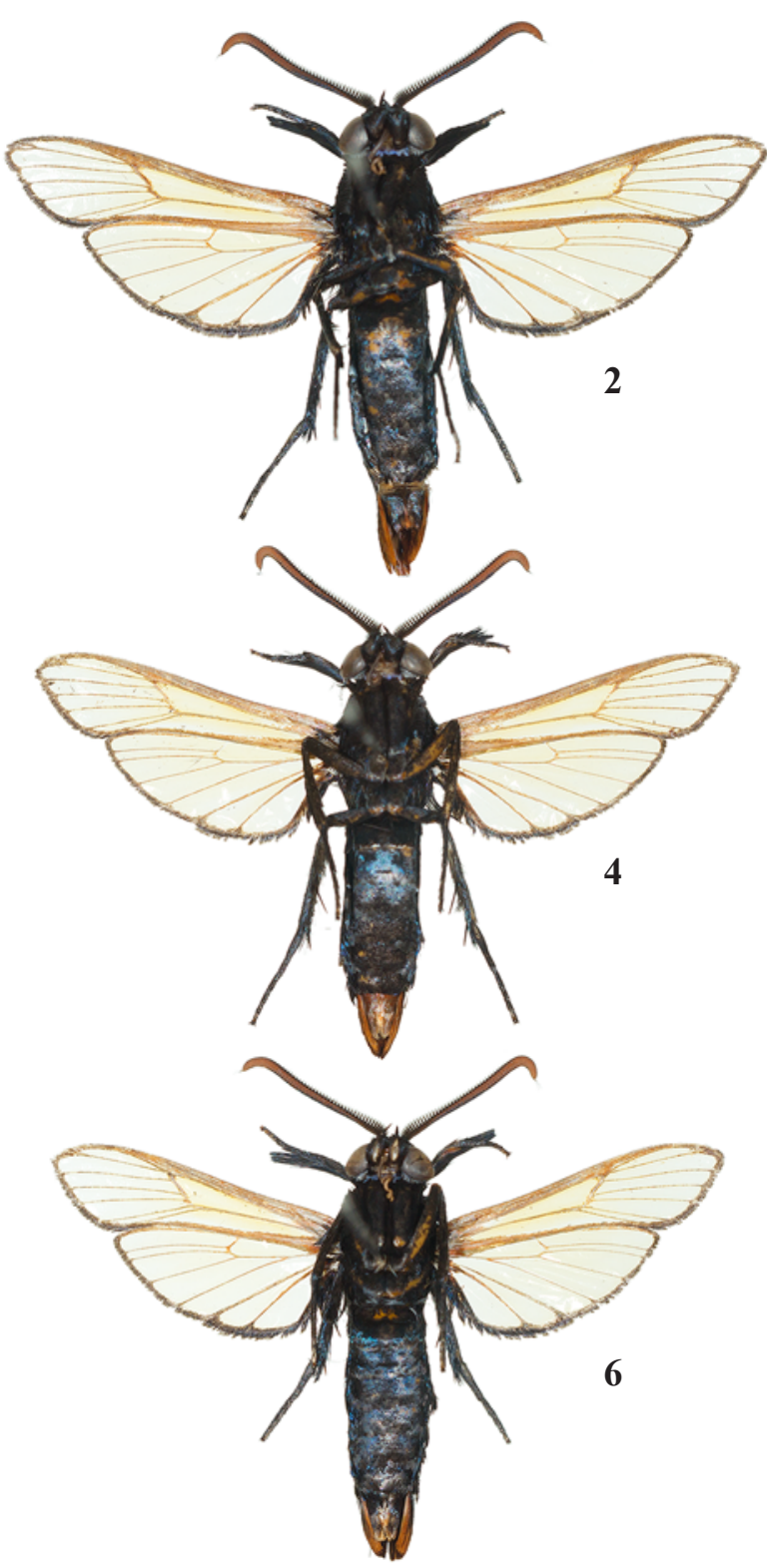

Figs 1-6. Variability of males of Taikona polevoyi sp.n.: 1-2 - holotype, alar expanse $36.0 \mathrm{~mm}$, Sesiidae pictures №№ 0061-2013, 0062-2013; 3-4 - paratype, alar expanse $33.2 \mathrm{~mm}$, Sesiidae pictures №№ 0063-2013, 0064-2013; 5-6 - paratype, alar expanse $31.8 \mathrm{~mm}$, Sesiidae pictures №№ 0065-2013, 0066-2013; 1, 3, 5 - upside; 2, 4, 6 - underside.

Рис. 1-6. Изменчивость самцов Taikona polevoyi sp.n.: 1-2 - голотип, размах крыльев 36,0 мм, Sesiidae снимки №№ 0061-2013, 0062-2013; 3-4 - паратип, размах крыльев 33,2 мм, Sesiidae снимки №№ 0063-2013, 0064-2013; 5-6 - паратип, размах крыльев 31.8 мм, Sesiidae снимки №№ 0065-2013, 0066-2013; 1, 3, 5 - сверху; 2, 4, 6 - снизу. 
0062-2013 / Photo by O. Gorbunov", "Genitalia examined / by O. Gorbunov / Preparation № / OG-005-2018”, "HOLOTYPUS O" Nokona polevoyi / O. Gorbunov, 2018 / O. Gorbunov des., 2016".

Paratypes $\left(2 \sigma^{7} \sigma^{7}\right), 1 \sigma^{7}$ (Figs 3-4) with labels: "Malaysia, Pahang Prov., / Kauntan, Swiss Garden / Resort, 035' $55^{\prime}$, $103^{\circ} 22^{\prime}$ E, / 10.III.2011, / E. Polevoy leg.”, “SESIIDAE / Pictures №№ 0063-0064-2013 / Photo by O. Gorbunov", "PARATYPUS $\sigma^{7}$ Nokona polevoyi / O. Gorbunov, 2018 / O. Gorbunov des., 2016"; 1 $\sigma^{7}$ (Figs 5-6) with labels: "Malaysia, Pahang Prov., / Kauntan, Swiss Garden / Resort, 03552 N, $103^{\circ} 222$ E, / 07.III.2011, / E. Polevoy leg.", "SESIIDAE / Pictures №№ / 0065-0066-2013 / Photo by O. Gorbunov", "PARATYPUS $\sigma^{7}$ / Nokona polevoyi / O. Gorbunov, 2018 / O. Gorbunov des., 2016".

DESCRIPTION. Male (holotype) (Figs 1-2). Alar expanse $36.0 \mathrm{~mm}$; body length $22.5 \mathrm{~mm}$; forewing $16.2 \mathrm{~mm}$; antenna $8.7 \mathrm{~mm}$.

Head with antenna black with dark violet sheen dorsally and light brown both ventrally and apically, scapus black with dark violet sheen; frons entirely dark brown to black with bronze-violet sheen; vertex and labial palpus black with dark violet sheen; occipital fringe black with dark violet sheen with a tuft of white hairs at ocellus.
Thorax with patagia black with dark violet sheen; tegula, meso- and metathorax entirely black with bronze-violet sheen; thorax laterally black with dark violet sheen; posteriorly both metepimeron and metameron black with dark violet sheen covered with long black and white hairs. Legs with neck plate black with greenish-violet sheen and an admixture of a few snow-white scales; fore coxa black with greenish-violet sheen; other parts of legs black with dark violet sheen. Forewing transparent; basally dull black; costal and anal margins, $\mathrm{CuA}-$ stem, veins $\mathrm{R}_{4}-\mathrm{CuA} \mathrm{A}_{2}$ and cross-vein narrowly black with dark violet sheen and an admixture of individual light brown scales; outer margin extremely narrow, about $1 / 2$ times as broad as cilia, dark brown to black with dark violet sheen; cilia dark brown to black with bronze-violet sheen; ventrally costal and anal margins, $\mathrm{CuA}$-stem, veins $\mathrm{R}_{4}-\mathrm{CuA}_{2}$ and crossvein narrowly light brown; outer margin dark brown to black with dark violet sheen; cilia dark brown to black with bronzeviolet sheen. Hindwing transparent; dorsally veins narrowly light brown with an admixture of dark brown scales in distal half (vein 1A entirely dark brown to black with dark violet sheen); discal spot undeveloped; outer margin narrow, dark
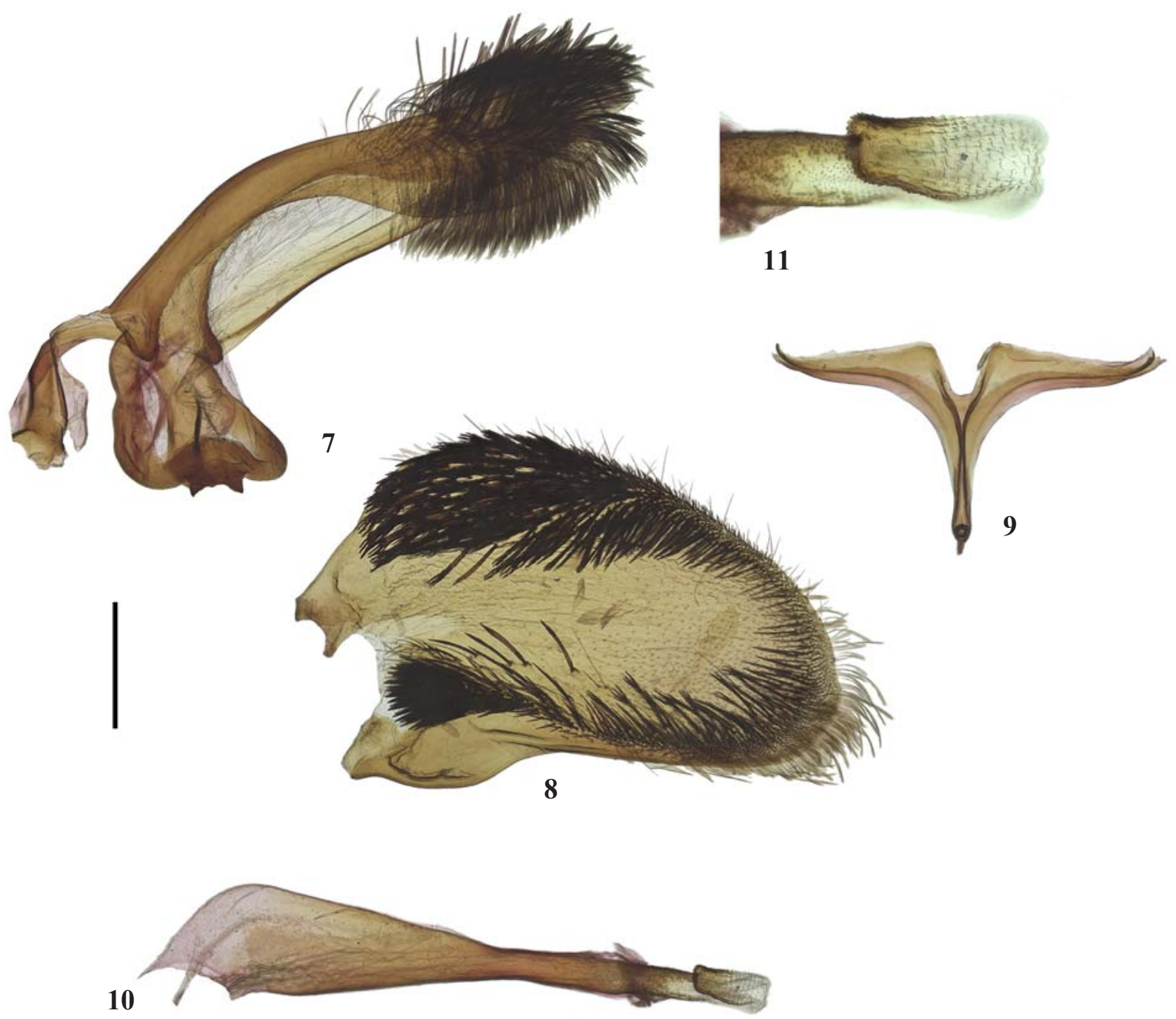

Figs 7-11. Male genitalia of Taikona pole 8 - valva; 9 - saccus; 10 - aedeagus; 11

Рис. 7-11. Гениталии самца Taikona pole 8 - вальва; 9 - саккус; 10 - эдеагус; 11

, genitalia preparation № OG-005-2018: 7 — tegumen-uncus complex; $0.5 \mathrm{~mm}$ for $7-10$ and 0.25 for 11

, препарат гениталий № OG-005-2018: 7 — тегумен-ункус комплекс; б 0,5 для рис. 7-10 и 0,25 для 11 . 
brown with dark violet sheen, about $1 / 3$ as broad as cilia (somewhat broader between veins $\mathrm{CuP}-1 \mathrm{~A}$ ); cilia dark brown to black with bronze-violet sheen; ventrally veins light brown, outer margin dark brown with dark violet sheen; cilia dark brown to black with bronze-violet sheen.

Abdomen dorsally entirely black with dark bluish-violet sheen; tergite 3 with a few show-white scales laterodistally; ventrally dark brown with dark bluish-violet sheen; sternites $1+2$ and 3 each with a few white scales at distal margin; anal tuft dark brown to black with dense admixture of dark redbrown scales, more bright ventrally.

Male genitalia (holotype) (genital preparation № OG005-2018) (Figs 7-11). Uncus narrow, distinctly broadened distally, densely covered with flat scales in broadened distal part; tegumen narrow; gnathos narrow, with double tooth; tuba analis with subscaphium narrowly sclerotized (Fig. 7); valva (Fig. 8) triangular-oval, densely covered with handshaped setae at dorsal margin in basal half, short simple setae at distal margin and hand-shaped setae at ventral margin in distal half; crista sacculi low, densely covered with strong pointed setae; saccus (Fig. 9) about as long as vinculum, straight, somewhat pointed basally; aedeagus (Fig. 10) rather broad, slightly longer than valva, with a flat well-sclerotized carina penis dorsodistally; vesica (Fig. 11) with numerous rows of minute flat cornuti.

Female. Unknown.

INDIVIDUAL VARIABILITY. The specimens of the type series (Figs 1-6) are practically invariable in the coloration of various parts of the body. The individual size is variable as follows: alar expanse $31.8-36.0 \mathrm{~mm}$; body length $20.0-22.5$ $\mathrm{mm}$; forewing 14.2-16.2 mm; antenna $8.0-8.7 \mathrm{~mm}$.

DIFFERENTIAL DIAGNOSIS. This new species is easily distinguishable from all other congeners by the absence of coloured (yellow or yellow-orange) scales on the head, thorax, legs and abdomen. Species of the genus Taikona can be identified using the following key based on the external characters:

1 Head, thorax, legs and abdomen with neither yellow nor yellow-orange scales ... T. polevoyi O. Gorbunov, sp.n.

- Head, thorax, legs and abdomen with yellow or yelloworange scales

2 Outer margin of forewing undeveloped; discal spot of hindwing undeveloped; abdomen dorsally with tergites 2 , 4 and 6 each with a narrow yellow stripe distally ......... T. matsumurai Arita et O. Gorbunov, 2001

- Outer margin of forewing narrow, but present; discal spot of hindwing narrow, with parallel margins; abdomen dorsally with tergites 2 and 3 each with a narrow yellow stripe distally, tergite 6 entirely yellow

T. actinidiae (Yang et Wang, 1989), comb.n. BIONOMICS. The host plant and larval bionomics are unknown. The type series was collected with the use of artificial sex attractants in the beginning of March. They were active slightly before noon at about 10-12 a.m. local time.

HABITAT. The type series was collected in forest thickets on sand dunes by sea shore (Fig. 12).

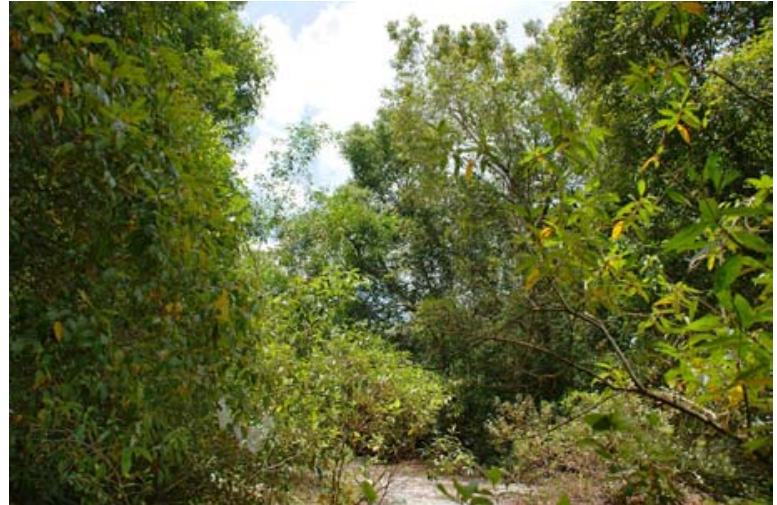

Fig. 12. Habitat of Taikona polevoyi sp.n. Malaysia, Pahang Prov., Kauntan, Swiss Garden Resort, 035' N, $103^{\circ} 22^{\prime} \mathrm{E}$, 07.III.2011. Photo by E. Polevoy.

Рис. 12. Биотоп Taikona polevoyi sp.n. Малайзия, провинция Паханг, Куантан, Швейцарский сад, 035' с.ш., $103^{\circ} 22^{\prime}$ в.д., 07.III.2011. Фото Е. Полевого.

DISTRIBUTION. Known only from the type locality in the continental part of Malaysia.

ETYMOLOGY. This new species is named after my friend Mr. Eugeniy Polevoy (Moscow, Russia) who collected the type series.

ACKNOWLEDGEMENTS. I express my cordial gratitude to Mr. Eugeniy Polevoy (Moscow, Russia) for his kind support to my study of Oriental Sesiidae. I also thank Dr. Sergei I. Golovatch (Moscow, Russia) for his linguistic help.

The study was conducted using the equipment of the Joint Usage Center "Instrumental methods in ecology" at the A.N. Severtsov Institute of Ecology and Evolution, Russian Academy of Sciences (Moscow, Russia).

\section{References}

Arita Y. 2011. Sesiidae // M. Wang, Y. Kishida (eds.). Moths of Guangdong Nanling National Nature Reserve. Keltern: Goecke \& Evers. P.37-38. P1.3

Arita Y., Gorbunov O. 2001. Sesiidae of Taiwan. I. The Tribes Tinthiini, Similipepsini, Paraglosseciini, Pennisetiini, Paranthrenini and Cissuvorini // Jpn. J. syst. Ent. Vol.7. No.2. P.131188.

Gorbunov O.G. 2016. Nokona mahawu sp. n., a new clearwing moth species (Lepidoptera, Sesiidae) from North Sulawesi, Indonesia // Russian Entomol. J. Vol.25. No.2. P.161-165.

Kallies A., Arita Y., Owada M., Wu G.-Y., Wang M. 2014. The Paranthrenini of Mainland China (Lepidoptera, Sesiidae) // Zootaxa. Vol.3811. No.2. P.185-206.

Yata N., Onodera S., Arita Y. 2017. Taxonomical status of Paranthrene yesonica Matsumura, 1931 (Lepidoptera, Sesiidae) // Tinea. Vol.23. No.6. P.295-305. 